\title{
DETERMINAN PERILAKU PERNIKAHAN DINI BERDASARKAN PERSPEKTIF KESEHATAN REPRODUKSI AMAN DAN FIQIH ISLAM
}

\author{
Widia Shofa Ilmiah *1), Fifin Maulidatul Azizah ${ }^{2)}$, Nova Hikmawati ${ }^{3)}$ \\ ${ }^{1)}$ Program Studi Sarjana Terapan Kebidanan, ITSK RS dr. Soepraoen \\ ${ }^{2,3)}$ Program Studi S1 Kebidanan, STIKES Hafshawaty Pesantren Zainul Hasan \\ email: widiailmiah86@gmail.com
}

\begin{abstract}
Abstrak
Pernikahan dini masih menjadi permasalahan kependudukan dan kesehatan reproduksi perempuan global. Data pernikahan dini dunia tahun 2015 (142 juta), di Indonesia tahun 2013 (2.6\%) menikah umur <15 tahun, 23.9\% menikah umur 15-19 tahun, tahun 2018 (1,5 juta) menikah <17 tahun; di Jawa Timur tahun 2015 (8.99\%), tahun 2016 (21.16\%), di Kabupaten Probolinggo tahun 2015 (21.02\%), tahun 2016 (41.18\%), hasil studi pendahuluan di Desa Patalan Wonomerto kepada 10 ibu diketahui 7 ibu (70\%) menikah umur $<17$ tahun. Tujuan penelitian menganalisis determinan paling dominan mempengaruhi perilaku pernikahan dini berdasarkan perspektif kesehatan reproduksi aman dan fiqih islam. Penelitian desain analitik korelasi dengan pendekatan cross sectional, populasi seluruh ibu yang memiliki anak remaja di Wonomerto 45 orang, sampel 40 orang, teknik simple random sampling, instrumen kuesioner, uji statistik multiple regresi logistik. Hasil penelitian tingkat pendidikan p 0.999 $>\alpha$ 0.05; sikap responden $p 0.365>\alpha 0.05$; tingkat pengetahuan $p 0.006$ dengan nilai $1 / P R=52.632$ dan niat p 0.012 dengan nilai 1/Prevalence Ratio $(1 / P R)=40.000$. Kesimpulan bahwa tingkat pengetahuan memiliki pengaruh 52 kali terhadap perilaku pernikahan dini. Oleh karena itu, penting bagi bidan sebagai garda terdepan untuk memberikan KIE setiap melakukan pelayanan terkait kesehatan reproduksi remaja.
\end{abstract}

Kata kunci : determinan, pernikahan dini, kesehatan reproduksi, fiqih islam

Abstract
Early marriage is still a global women's population and reproductive health problem. Data on early marriage in the world in 2015 (142 million), Indonesia in 2013 (2.6\%) married $<15$ y.o, and 23.9\% married on 15-19 y.o, in 2018 (1.5 million) married < 17 y.o; in East Java in 2015 (8.99\%), in 2016 (21.16\%), in Probolinggo Regency in 2015 (21.02\%), in 2016 (41.18\%), the preliminary study in Patalan Wonomerto to 10 mothers found 7 mothers (70\%) were married $<17$ y.o. The purpose to analyze the most dominant determinants affecting early marriage behavior based on perspective of safe reproductive health and Islamic jurisprudence. This study a correlation analytic design a cross-sectional, population of 45 mothers with adolescent children in Wonomerto, sample were 40 people; simple random sampling, questionnaires, multiple logistic regression. The results that the level of education ( $p 0.999>$ $0.05)$, attitude $(p 0.365>0.05)$, level of knowledge $p 0.006$ with $(1 / P R)=52.632$; intention $p$ $0.012,(1 / P R)=40,000$. The conclusion that the level of knowledge has an effect of 52 times on early marriage behavior. It is important for midwives as the front line to provide IEC every time at provide services related to adolescent reproductive health.

Keywords: determinant, early marriage, health reproduction, fiqih Islam

\section{PENDAHULUAN}

Perkawinan merupakan pembentukan sebuah keluarga dengan lawan jenis yaitu lakilaki dan perempuan serta melakukan hubungan kelamin dan bersetubuh (Rifiani, 2011). Pernikahan dini yaitu ikatan antara laki-laki dan perempuan yang berada pada tahapan usia masa remaja yang menjalin hidup bersama dalam satu ikatan keluarga.

Data pernikahan dini di dunia pada tahun 2015, ada sekitar 142 juta anak perempuan melakukan pernikahan sebelum waktunya (Muntamah et al, 2019). 
Data pernikahan dini di Indonesia menurut Riset Kesehatan Dasar (Riskesdas) 2013 bahwa di antara perempuan 10-54 tahun, $2.6 \%$ menikah pertama kali pada umur $<15$ tahun, dan $23.9 \%$ menikah pada umur 15-19 tahun; Sedangkan pada tahun 2018 di indonesia diketahui bahwa sekitar 1.5 juta anak perempuan telah menikah dini, angka tersebut setara dengan gadis yang menikah setiap dua detiknya (Muntamah et al, 2019).

Data pernikahan dini di Jawa Timur tahun 2015 diketahui $8.99 \%$ dan pada tahun 2016 sebesar $21.16 \%$ perempuan menikah pada usia $<17$ tahun (Badan Pusat Statistik Jawa Timur, 2017). Data pernikahan dini di Kabupaten Probolinggo yang menduduki urutan ketiga setelah Bondowoso dan Situbondo pada tahun 2015 diketahui sebesar 21.02\% dan pada tahun 2016 sebesar $41.18 \%$ perempuan menikah pada usia $<17$ tahun, sedangkan data pernikahan dini di Desa Wonomerto sendiri berdasarkan hasil studi pendahuluan kepada 10 ibu dengan cara wawancara pada Januari 2019 diketahui bahwa sebanyak 7 ibu menikah pada usia $<17$ tahun.

Hasil studi pendahuluan tentang pernikahan dini dengan cara wawancara pada 10 ibu di Desa Wonomerto bahwa dari 10 ibu diketahui sebanyak 7 orang diantaranya memiliki pengetahuan yang rendah tentang kesehatan reproduksi yang aman, sedangkan 3 lainnya memiliki pengetahuan cukup baik dan 8 orang memiliki pengetahuan yang kurang tentang hukum (fiqih) islam tentang pernikahan dini, serta 2 orang memiliki pengetahuan cukup tentang fiqih islam. Dari $10 \mathrm{ibu}$ diketahui status sosial ekonomi sebanyak 6 orang adalah rendah dan 4 orang memiliki status sosial ekonomi tinggi dengan tingkat pendidikan sebanyak 7 orang adalah lulusan SD. Selain itu, terkait pernikahan dini, dari 10 ibu diketahui 8 ibu memiliki sikap dan niat untuk menikahkan anaknya pada usia remaja atau menikahkan lebih dini.

Penyebab terjadinya pernikahan dini yaitu masih rendahnya pengetahuan ibu tentang kesehatan reproduksi yang aman, rendahnya pengetahuan tentang fiqih islam tentang pernikahan, status sosial ekonomi, tingkat pendidikan yang rendah, serta adanya sikap negatif tentang pernikahan dini dan niat berperilaku menikahkan dini anaknya. Menurut (Rifiani, 2011) dan (Pohan, 2017) faktor penyebabnya antara lain status sosial ekonomi, tingkat pendidikan, tingkat pengetahuan tentang kesehatan reproduksi, orang tua, media massa, budaya/ adat khususnya masyarakat pedesaan yang memiliki kebiasaan menikah muda dan adanya keyakinan bahwa perempuan yang telah mengalami menstruasi pertama telah layak untuk menikah, broken home serta pemahaman agama atau fiqih Islam dan adanya keyakinan bahwa apabila seorang anak telah memiliki hubungan dekat dengan lawan jenis, maka orang tua harus mengambil keputusan untuk menikahkan remaja tersebut agar terhindar dari hal-hal yang tidak diinginkan.

Dampak melakukan pernikahan dini yaitu terhadap kesehatan fisik, mental maupun masyarakat. Dampak kesehatan karena menikah dini pada perempuan yaitu memiliki angka kematian yang tinggi disebabkan proses melahirkan hingga kematian bayi dan melahirkan yang aman yaitu antara usia 20-35 tahun (Rifiani, 2011). Dampak fisik pernikahan dini yaitu belum siap dibebani suatu pekerjaan yang memerlukan keterampilan fisik untuk mendatangkan penghasilan dan mencukupi kebutuhan keluarga. Dampak mental pernikahan usia dini atau remaja yaitu kesiapan moral dan mental dalam menghadapi kehidupan berrumah tangga masih kurang. Sedangkan dampak masyarakat atau aspek kependudukan yaitu pernikahan dini memiliki angka kesuburan yang sangat tinggi sehingga dapat menimbulkan meledaknya jumlah penduduk yang dapat mengakibatkan kurangnya dukungan pembangunan dibidang kesejahteraan masyarakat (Arikhman et al., 2019).

Upaya yang telah dilakukan pemerintah untuk mengatasi semakin meningkatnya angka pernikahan dini meliputi disahkannya RUU tentang perkawinan yaitu RUU No. 12 Pasal 73 ayat (1) tahun 2011 bahwa menikah baik laki-laki dan perempuan jika usianya minimal mencapai 19 tahun. Upaya lainnya yang dapat dilakukan yaitu memberikan pendidikan kesehatan tentang pernikahan 
dan dampaknya dalam berbagai aspek termasuk kesehatan reproduksi khususnya perempuan.

Tujuan penelitian ini yaitu menganalisis determinan yang paling dominan mempengaruhi perilaku pernikahan dini berdasarkan perspektif kesehatan reproduksi aman dan fiqih Islam di Wonomerto Kabupaten Probolinggo.

\section{METODE PENELITIAN}

Desain penelitian ini menggunakan studi observasional jenis analitik korelasi dengan pendekatan cross sectional. Populasinya adalah seluruh ibu yang memiliki anak remaja di Wonomerto Kabupaten Probolinggo sejumlah 45 orang. Teknik pengambilan sampel secara simple random sampling. Jumlah sampel penelitian ini sebanyak 40 orang. Kriteria inklusi penelitian yaitu ibu yang memiliki anak remaja puteri dan bersedia diteliti. Kriteria eksklusi penelitian yaitu ibu yang tidak datang pada saat penelitian berlangsung. Variabel bebas penelitian ini yaitu status sosial ekonomi, tingkat pendidikan, tingkat pengetahuan, sikap, niat dan variabel tergantung penelitian ini yaitu perilaku.

Pengumpulan data dilakukan oleh tim peneliti dengan cara mengundang responden ke Balai Desa Wonomerto, menjelaskan prosedur penelitian, melakukan informed consent. Selanjutnya, menyebarkan kuesioner, menjelaskan cara pengisian kuesioner dan mengecek kembali kelengkapan isian kuesioner responden lalu dikumpulkan ke peneliti. Analisis data penelitian univariat menggunakan distribusi frekuensi, analisis bivariat menggunakan Chi Square dan analisis multivariat menggunakan multiple regresi logistic dengan bantuan SPSS v.16. Sebelum dilakukan penelitian, terlebih dahulu dilakukan kaji etik di STIKes Hafshawaty Pesantren Zainul Hasan dengan nomor SK KEPK/ 014/ STIKes-HPZH/II/2021.

\section{HASIL DAN PEMBAHASAN}

Berdasarkan data karakteristik responden bahwa status sosial ekonomi reponden hampir seluruhnya yaitu 36 orang $(90 \%)$ adalah rendah; 32 orang $(80 \%)$ berada pada tingkat dasar sampai dengan sekolah menengah pertama; sebagian besar ibu memiliki tingkat pengetahuan kurang baik tentang pernikahan dini yaitu sebanyak 25 orang $(62.5 \%)$; sebagian besar sikap ibu tentang pernikahan dini yaitu negatif sebanyak 23 orang $(57.5 \%)$; sebagian besar ibu memiliki niat untuk menikahkan remaja putrinya pada usia dini/ melakukan pernikahan dini sebanyak 24 orang (60\%); sebagian besar ibu memiliki perilaku negatif tentang pernikahan dini yaitu sebanyak 28 orang $(70 \%)$ (Tabel 1).

Berdasarkan hasil tabulasi silang dan analisis dengan uji Chi square diketahui bahwa responden yang memiliki status sosial ekonomi rendah cenderung memiliki perilaku negatif tentang pernikahan dini yaitu sebanyak 26 orang $(65 \%)$, sedangkan responden yang memiliki status sosial ekonomi tinggi diketahui memiliki perilaku keduanya baik negatif dan positif tentang pernikahan dini masing-masing sebanyak 2 orang $(5 \%)$. Hasil uji statistik chi square diperoleh nilai $\mathrm{p} 0.358>0.25$. Responden yang memiliki tingkat pendidikan dasar cenderung memiliki perilaku negatif tentang pernikahan dini yaitu sebanyak 28 orang (70\%), sedangkan responden yang memiliki tingkat pendidikan tinggi sebanyak 8 orang $(20 \%)$, memiliki perilaku positif tentang pernikahan dini. Hasil uji statistik chi square diperoleh nilai p $0.000<\alpha 0.25$. responden yang memiliki tingkat pengetahuan kurang baik cenderung memiliki perilaku negatif tentang pernikahan dini yaitu sebanyak 24 orang (60\%), sedangkan responden yang memiliki tingkat pengetahuan baik sebanyak 11 orang (27.5\%), memiliki perilaku positif tentang pernikahan dini. Hasil uji statistik chi square diperoleh nilai p $0.000<\alpha 0.25$. responden yang memiliki sikap negatif cenderung memiliki perilaku negatif tentang pernikahan dini yaitu sebanyak 24 orang (60\%), sedangkan responden yang memiliki sikap positif sebanyak 11 orang $(27.5 \%)$, memiliki perilaku positif tentang pernikahan dini. Hasil uji statistik chi square diperoleh nilai p $0,000<\alpha$ $=0.25$. Responden yang memiliki niat untuk berperilaku menikahkan remaja putrinya pada usia dini, cenderung memiliki perilaku negatif tentang pernikahan dini yaitu sebanyak 23 orang $(57.5 \%)$, sedangkan responden yang tidak ada niat untuk berperilaku menikahkan remaja putrinya pada usia dini, cenderung memiliki perilaku positif sebanyak 11 orang (27.5\%). Hasil uji statistik chi square diperoleh nilai p $0.000<\alpha 0.25$ (Tabel 2).

Berdasarkan hasil analisis multivariat diketahui bahwa tingkat pendidikan diperoleh $\mathrm{p}$ $0.999>\alpha 0.05$ dan sikap responden tentang pernikahan dini diperoleh p $0.365>\alpha 0.05$, sedangkan tingkat pengetahuan diperoleh $\mathrm{p}$ 
0.006 dengan nilai $1 /$ Prevalence Ratio $(1 / \mathrm{PR})=$ 52.632 dan niat untuk melakukan pernikahan dini diperoleh p 0.012 dengan nilai 1/Prevalence Ratio $(1 / \mathrm{PR})=40.000$. Hasil tersebut menunjukkan bahwa tingkat pendidikan dan sikap tidak berpengaruh terhadap perilaku pernikahan dini, sedangkan tingkat pengetahuan dan niat berpengaruh terhadap perilaku pernikahan dini serta tingkat pengetahuan diketahui dapat mempengaruhi perilaku sebanyak 52.632 kali, sedangkan niat berpengaruh terhadap perilaku sebanyak 40.000 kali.

Tabel 1. Karakteristik Responden

\begin{tabular}{ccc}
\hline $\begin{array}{c}\text { Karakteristik } \\
\text { Responden }\end{array}$ & $\mathbf{n = 4 0}$ & $\mathbf{\%}$ \\
\hline $\begin{array}{c}\text { Status Sosial Ekonomi } \\
\text { Rendah }\end{array}$ & 36 & 90.0 \\
Tinggi & 4 & 10.0
\end{tabular}

$\begin{array}{lcc}\text { Tingkat Pendidikan } & & \\ \quad \text { Dasar (SD, SMP) } & 32 & 80.0 \\ \text { Tinggi (SMA dan } & 8 & 20.0 \\ \begin{array}{l}\text { PT) } \\ \text { Tingkat Pengetahuan }\end{array} & & \\ \quad \text { Kurang baik } & 25 & 62.5 \\ \quad \text { Baik } & 15 & 37.5 \\ \text { Sikap } & & \\ \quad \text { Negatif } & 23 & 57,5 \\ \quad \text { Positif } & 17 & 42,5 \\ \text { Niat } & & \\ \quad \text { Ada Niat } & 24 & 60 \\ \quad \text { Tidak Ada Niat } & 16 & 40 \\ \text { Perilaku Pernikahan } & & \\ \text { Dini } & & \\ \quad \text { Negatif } & 28 & 70 \\ \quad \text { Positif } & 12 & 30 \\ \end{array}$

Tabel 2. Tabel Silang Karakteristik Responden terhadap Perilaku Pernikahan Dini

\begin{tabular}{|c|c|c|c|c|c|c|c|}
\hline \multirow{3}{*}{ Variabel } & \multicolumn{4}{|c|}{ Perilaku Pernikahan Dini } & & & \multirow{3}{*}{$\mathrm{p}(\alpha=0.05)$} \\
\hline & \multicolumn{2}{|c|}{ Negatif } & \multicolumn{2}{|c|}{ Positif } & \multicolumn{2}{|c|}{ Total $(n=40)$} & \\
\hline & $\mathbf{f}$ & $\%$ & $\mathbf{f}$ & $\%$ & $\mathbf{f}$ & $\%$ & \\
\hline \multicolumn{8}{|c|}{ Status Sosial Ekonomi } \\
\hline Rendah & 26 & 65,0 & 10 & 25,0 & 36 & 90,0 & 0,358 \\
\hline Tinggi & 2 & 5,0 & 2 & 5,0 & 4 & 10,0 & \\
\hline \multicolumn{8}{|l|}{ Tingkat Pendidikan } \\
\hline Dasar & 28 & 70,0 & 4 & 10,0 & 32 & 80,0 & 0,000 \\
\hline Tinggi & 0 & 0,0 & 8 & 20,0 & 8 & 20,0 & \\
\hline \multicolumn{8}{|l|}{ Tingkat Pengetahuan } \\
\hline Kurang Baik & 24 & 60,0 & 1 & 2,5 & 25 & 62,5 & 0.000 \\
\hline Baik & 4 & 10,0 & 11 & 27,5 & 15 & 37,5 & \\
\hline \multicolumn{8}{|l|}{ Sikap } \\
\hline Negatif & 22 & 55,0 & 1 & 2,5 & 23 & 57,5 & 0,000 \\
\hline Positif & 6 & 15,0 & 11 & 27.5 & 7 & 42,5 & \\
\hline \multicolumn{8}{|l|}{ Niat } \\
\hline Ada Niat & 23 & 57,5 & 1 & 2,5 & 24 & 60,0 & 0,000 \\
\hline Tidak Ada Niat & 5 & 12,5 & 11 & 27,5 & 16 & 40,0 & \\
\hline
\end{tabular}

Tabel 3. Regresi Logistik Berganda Determinan yang Paling Dominan Mempengaruhi Perilaku Pernikahan Dini Berdasarkan Perspektif Kesehatan Reproduksi Aman dan Fiqih Islam

\begin{tabular}{lccc}
\hline Variabel & $\mathrm{p}$ & $\begin{array}{l}\text { Prevalence } \\
\text { Ratio }(\mathrm{PR})\end{array}$ & $1 / \mathrm{PR}$ \\
\hline $\begin{array}{l}\text { Tingkat } \\
\text { Pendidikan }\end{array}$ & 0,999 & - & - \\
& & &
\end{tabular}

\begin{tabular}{lccc} 
Tingkat & 0,006 & 0,019 & 52.632 \\
Pengetahuan & & & \\
Sikap & 0,365 & - & - \\
Niat & 0,012 & 0,025 & 40.000 \\
\hline
\end{tabular}

Pengaruh Status Sosial Ekonomi terhadap Perilaku Pernikahan Dini Berdasarkan Perspektif Kesehatan Reproduksi Aman dan Fiqih Islam 
Hasil penelitian menunjukkan bahwa hampir seluruh status sosial ekonomi responden yaitu rendah dan hasil analisis chi square diketahui status sosial ekonomi tidak berpengaruh terhadap perilaku pernikahan dini berdasarkan perspektif kesehatan reproduksi aman dan fiqih Islam.

Status sosial ekonomi yaitu suatu kondisi status sosial seseorang di masyarakat yang dinilai berdasarkan penghasilan yang diperolehnya setiap bulannya (Pohan, 2017). Perilaku kesehatan merupakan suatu respon individu terhadap suatu stimulus yang berkaitan dengan sakit dan penyakit serta sistem pelayanan kesehatan, makanan, minuman dan lingkungan (Notoatmodjo, 2012).

Responden dalam kelompok penelitian ini hampir seluruhnya memiliki status sosial ekonomi rendah dan sebagian dari mereka melakukan praktik pernikahan dini. Sebagian lagi dari mereka lebih memilih untuk menyekolahkan anaknya sampai taraf sekolah menengah atas dan atau perguruan tinggi melalui program beasiswa dari pemerintah untuk anak tidak mampu dan program beasiswa berprestasi. Rata-rata usia anak yang lulus sekolah menengah atas yaitu antara 18-19 tahun dan rata-rata usia anak yang lulus perguruan tinggi mulai taraf diploma hingga sarjana yaitu 21-24 tahun.

Hasil penelitian peneliti didukung oleh penelitian sebelumnya menurut (Aulia et al, 2013) bahwa penghasilan orang tua atau keluarga di Sambas hampir seluruhnya memiliki penghasilan di bawah Upah Minimum Kabupaten (UMK). Namun, baik dari responden yang memiliki upah tidak sesuai atau pun sesuai UMK diketahui bukan merupakan alas an orang tua untuk menikahkan anaknya pada usia muda atau dini. Namun, ada faktor lainnya yang diyakini menjadi faktor pengambilan keputusan untuk menikah atau tidak menikah pada usia muda yaitu motivasi melanjutkan pendidikan ke jenjang yang lebih tinggi, serta pengetahuan remaja tentang usia menikah yang baik, pengetahuan remaja tentang dampak menikah dini baik dari aspek kesehatan dan aspek kesiapan mental.

\section{Pengaruh Tingkat Pendidikan Orang Tua terhadap Perilaku Pernikahan Dini Berdasarkan Perspektif Kesehatan Reproduksi Aman dan Fiqih Islam}

Hasil penelitian menunjukkan bahwa hampir seluruh tingkat pendidikan responden berada pada tingkat dasar sampai dengan sekolah menengah pertama dan hasil analisis chi square diketahui tingkat pendidikan responden berpengaruh terhadap perilaku pernikahan dini berdasarkan perspektif kesehatan reproduksi aman dan fiqih islam.

Tingkat pendidikan menurut UU Sisdiknas (2012) merupakan level pendidikan seseorang yang diperoleh melalui pendidikan formal. Faktor yang mempengaruhi pengetahuan menurut (Ilmiah et al, 2017) meliputi faktor Internal, yaitu pendidikan, pekerjaan, umur dan faktor eksternal yaitu faktor lingkungan dan sosial budaya. Semakin tinggi tingkat Pendidikan seseorang, maka semakin baik juga pengetahuan orang tersebut. Hal ini yang akan mempengaruhi seseorang dalam berperilaku, salah satunya dalam pengambilan keputusan untuk menikahkan putrinya pada usia dini.

Menurut (Sah et al., 2014) bahwa tingkat pendidikan orang tua akan mempengaruhi perilaku menikah dini. Dalam kehidupan di masyarakat, orang tua memiliki peran penting dalam keputusan pernikahan anak mereka. Demikian juga menurut (Nasrin, 2012) bahwa pendidikan merupakan faktor utama yang memperngaruhi penundaan usia menikah. Seseorang yang memiliki tingkat pendidikan lebih tinggi cenderung akan menunda usia pernikahannya hingga mencapai usia yang matang. Hal ini dikarenakan seseorang yang memiliki tingkat Pendidikan yang tinggi juga diiringi dengan tingkat pengetahuan yang baik termasuk faktor kesiapan baik fisik atau organ reproduksi, psikis dan ekonomi yang dapat mempengaruhi keharmonisan rumah tangganya.

Seseorang yang memiliki tingkat pendidikan yang tinggi memahami bahwa meskipun menurut ajaran yang diyakini dalam hal ini adalah agama islam yaitu diperbolehkan atau sunnah dengan 
ketentuan telah memenuhi syarat hukum menikah dan dengan tujuan untuk menghindari perzinahan, maka orang yang memiliki pendidikan semakin tinggi akan mempertimbangkan pengambilan keputusan untuk menikah dini atau menikahkan anaknya pada usia dini karena dengan menikah dini diyakini akan banyak dampak yang dirasakan meliputi kepribadian yang kurang matang atau belum siap menghadapi problem berrumah tangga, banyak masalah kehamilan pada usia dini, kesulitan dalam membiayai keluarganya.

\section{Pengaruh Tingkat Pengetahuan Orang Tua tentang Kesehatan Reproduksi Aman dan Fiqih Islam terhadap Perilaku Pernikahan Dini Berdasarkan Perspektif Kesehatan Reproduksi Aman dan Fiqih Islam}

Hasil penelitian menunjukkan bahwa sebagian besar responden memiliki tingkat pengetahuan kurang baik tentang pernikahan dini dan dampaknya baik dari aspek Kesehatan reproduksi dan fiqih Islam. Namun, pada hampir sebagian responden yang berpengetahuan baik, cenderung memiliki perilaku positif. Hasil analisis chi square diketahui tingkat pengetahuan berpengaruh terhadap perilaku pernikahan dini berdasarkan perspektif kesehatan reproduksi aman dan fiqih islam.

Pengetahuan merupakan hasil dari tahu, dan hal ini terjadi setelah seseorang melakukan penginderaan terhadap suatu obyek tertentu. Faktor-faktor yang mempengaruhi pengetahuan meliputi faktor internal, yaitu pendidikan, pekerjaan, umur dan faktor eksternal yaitu faktor lingkungan dan sosial budaya (Ilmiah et al, 2017). Hasil penelitian peneliti di dukung oleh penelitian (Pohan, 2017) bahwa seseorang yang memiliki pengetahuan kurang baik memiliki risiko 6,19 kali untuk menikah pada usia dini. Rendahnya pengetahuan responden dikarenakan kurangnya informasi petugas kesehatan dalam melakukan promosi kesehatan tentang permasalahan yang berkaitan dengan pernikahan dini, usia ideal untuk menikah dan aman untuk berreproduksi.

Sedangkan menurut (Arikhman et al, 2019) bahwa seseorang yang memiliki pengetahuan yang baik cenderung tidak menikah pada usia dini, karena mereka telah memperoleh pengetahuan tentang pernikahan usia dini dari lingkungan sekitar mereka dengan melihat kehidupan pasangan muda yang melakukan perkawinan usia muda serta sebagian besar kehidupan pasangan muda tersebut mengalami kesulitan dalam bidang ekonomi.

\section{Pengaruh Sikap Orang Tua terhadap Perilaku Pernikahan Dini Berdasarkan Perspektif Kesehatan Reproduksi Aman dan Fiqih Islam}

Hasil penelitian menunjukkan bahwa sebagian besar sikap ibu tentang pernikahan dini yaitu negatif cenderung memiliki perilaku negatif tentang pernikahan dini dan dari sebagian responden yang memiliki sikap positif diketahui memiliki perilaku positif tentang pernikahan dini. Hasil analisis chi square menunjukkan bahwa sikap berpengaruh terhadap perilaku pernikahan dini berdasarkan perspektif kesehatan reproduksi aman dan fiqih islam.

Sikap merupakan respon atau tanggapan seseorang terhadap sesuatu hal (Notoatmodjo, 2012). Faktor yang mempengaruhi sikap seseorang yaitu pengalaman pribadi, pengaruh orang lain yang dianggap penting, budaya, media massa, kepercayaan, emosional (Azwar, 2011).

Menurut (Kumaidi et al., 2014) bahwa terdapat hubungan antara sikap dan dengan pernikahan dini pada remaja puteri. Remaja yang memiliki sikap negative tentang pernikahan dini karena tidak mengetahui dampak yang ditimbulkan. Adapun dampak pernikahan dini yaitu permasalahan keuangan, tanggung jawab, kematangan organ reproduksi, psikis dan kematangan sosial. Sikap yang di tunjukkan remaja juga akan menjadi salah satu faktor sikap orang tua dalam pengambilan keputusan tentang pernikahan dini. Orang tua yang juga memiliki sikap negatif dikarenakan memiliki tingkat pengetahuan yang kurang tentang kesehatan reproduksi dan fiqih islam.

Pengaruh Niat Orang Tua terhadap Perilaku Pernikahan Dini Berdasarkan 


\section{Perspektif Kesehatan Reproduksi Aman dan Fiqih Islam}

Hasil penelitian menunjukkan bahwa sebagian besar ibu yang memiliki niat tentang pernikahan dini cenderung memiliki perilaku negatif tentang pernikahan dini atau berperilaku menikahkan remaja puterinya pada usia dini, dan dari sebagian responden yang tidak memiliki niat untuk menikahkan dini remaja puterinya diketahui juga memiliki perilaku positif tentang pernikahan dini. Hasil analisis chi square menunjukkan bahwa niat berpengaruh terhadap perilaku pernikahan dini berdasarkan perspektif kesehatan reproduksi aman dan fiqih islam.

Niat merupakan fungsi dari determinan dasar yaitu sikap individu terhadap perilaku (merupakan aspek personal) dan persepsi individu terhadap tekanan sosial untuk melakukan atau untuk tidak melakukan perilaku (norma subyektif) (Ilmiah et al, 2017). Niat dipengaruhi oleh beberapa faktor menurut (Ilmiah et al, 2017), yaitu sikap, norma subyektif (keyakinan dan motivasi), kontrol persepsi perilaku (perceived behavioral control).

Hasil penelitian peneliti sesuai dengan penelitian (Juniata, 2016) bahwa niat mempengaruhi perilaku untuk mengambil keputusan menikah dini dan niat ditentukan oleh faktor kontrol persepsi perilaku (perceived behavioral control). Aspek kontrol persepsi perilaku orang tua akan mempengaruhi niat dan keputusan orang tua untuk menikahkan puterinya pada usia dini atau remaja. Semakin tinggi peluang orang tua untuk berperilaku menikahkan dini puterinya, maka semakin tinggi juga niat orang tua untuk melakukan pernikahan dini terhadap anaknya.

\section{Determinan yang Paling Dominan Mempengaruhi Perilaku Pernikahan Dini Berdasarkan Perspektif Kesehatan Reproduksi Aman dan Fiqih Islam}

Hasil penelitian menunjukkan bahwa hasil uji statistik regresi logistik berganda diketahui bahwa tingkat pendidikan dan sikap tidak berpengaruh terhadap perilaku pernikahan dini, sedangkan tingkat pengetahuan dan niat berpengaruh terhadap perilaku pernikahan dini serta tingkat pengetahuan merupakan determinan yang paling dominan mempengaruhi perilaku pernikahan dini sebanyak 52 kali berdasarkan perspektif kesehatan reproduksi aman dan fiqih islam.

Faktor yang mempengaruhi pernikahan dini menurut (Rifiani, 2011) dan (Pohan, 2017) antara lain status sosial ekonomi, tingkat pendidikan, tingkat pengetahuan tentang kesehatan reproduksi, faktor orang tua, media massa, budaya/ adat khususnya masyarakat pedesaan yang memiliki kebiasaan menikah muda dan adanya keyakinan bahwa perempuan yang telah mengalami menstruasi pertama telah layak untuk menikah, faktor broken home, pemahaman agama atau fiqih Islam dan adanya keyakinan bahwa apabila seorang anak telah memiliki hubungan dekat dengan lawan jenis, maka orang tua harus mengambil keputusan untuk menikahkan remaja tersebut agar terhindar dari hal-hal yang tidak diinginkan serta faktor lingkungan.

Hasil penelitian peneliti berbeda dengan beberapa penelitian sebelumnya bahwa tingkat pendidikan tidak selalu menentukan perilaku seseorang untuk berperilaku positif termasuk tentang pernikahan dini. Hasil penelitian peneliti didukung oleh penelitian (Hotchkiss et al., 2016) bahwa tingkat pendidikan tidak selalu mempengaruhi keputusan menikah dini. Hal ini dikarenakan masih banyak faktor lain yang lebih berperan mempengaruhi menikah dini yaitu budaya, faktor lingkungan tempat tinggal, tingkat pengetahuan. Penelitian lainnya mengatakan bahwa faktor yang berperan dalam pernikahan dini yaitu pengetahuan, budaya dan dukungan keluarga. Tingginya pengetahuan seseorang tidak selalu diperoleh melalui Pendidikan formal. Pengetahuan juga dapat diperoleh secara mandiri melalui berbagai media. Selain itu, peranan budaya di lingkungan tempat tinggal menjadi faktor penentu untuk menikah dini. Hal ini dikarenakan ada pandangan bahwa anak yang menikah pada usia muda memiliki penilaian yang lebih dibandingkan yang terlambat menikah. Selanjutnya, dukungan keluarga untuk menikah dini juga menjadi faktor penting 
dalam pengambilan keputusan untuk menikah pada usia dini (Adam et al., 2013).

Selanjutnya, menurut (Angraini et al., 2019) tidak ada hubungan antara sikap dengan usia menikah. Remaja dan orang tua yang memiliki sikap negatif, belum tentu memiliki perilaku menikah dini. Dalam penelitian ini faktor yang mempengaruhinya yaitu pengetahuan dan paparan media massa/media sosial.

Hasil penelitian peneliti menunjukkan bahwa tingkat pengetahuan dan niat berpengaruh terhadap pernikahan dini. Hal ini sejalan dengan penelitian (Arikhman, et al., 2019) bahwa seseorang yang memiliki pengetahuan yang baik cenderung tidak menikah pada usia dini, karena mereka telah memperoleh pengetahuan tentang pernikahan usia dini dari lingkungan sekitar mereka dengan melihat kehidupan pasangan muda yang melakukan perkawinan usia muda serta sebagian besar kehidupan pasangan muda tersebut mengalami kesulitan dalam bidang ekonomi.

Selanjutnya penelitian (Juniata, 2016) mengatakan bahwa niat mempengaruhi perilaku untuk mengambil keputusan menikah dini dan niat ditentukan oleh faktor kontrol persepsi perilaku (perceived behavioral control). Aspek kontrol persepsi perilaku orang tua akan mempengaruhi niat dan keputusan orang tua untuk menikahkan puterinya pada usia dini atau remaja. Semakin tinggi peluang orang tua untuk berperilaku menikahkan dini puterinya, maka semakin tinggi juga niat orang tua untuk melakukan pernikahan dini terhadap anaknya.

Berdasarkan hasil analisis pada penelitian ini tingkat pengetahuan paling dominan mempengaruhi perilaku pernikahan dini sebanyak 52 kali berdasarkan perspektif kesehatan reproduksi aman dan fiqih islam dibandingkan niat. Hal ini sesuai dengan pendapat beberapa peneliti bahwa pengetahuan meskipun sebagai faktor tidak langsung yang mempengaruhi perilaku terbukti efektif menentukan perilaku seseorang. Pengetahuan seseorang dapat diperoleh dari pengalaman lingkungan sekitar, informasi dari media masa atau media sosial dan faktor lingkungan yang membentuk pengetahuan seseorang berperan penting dalam membentuk sebuah perilaku. Perilaku seseorang menjadi positif atau pun negatif ditentukan karena faktor pengetahuan orang tersebut terhadap sesuatu hal. Sedangkan niat jika tidak diiringi dengan wujud sikap seseorang dan norma subyektif, maka dimungkinkan akan diurungkan untuk membentuk sebuah perilaku.

\section{KESIMPULAN DAN SARAN}

Tingkat pendidikan dan sikap tidak berpengaruh terhadap perilaku pernikahan dini, sedangkan tingkat pengetahuan dan niat berpengaruh terhadap perilaku pernikahan dini. Tingkat pengetahuan merupakan determinan yang paling dominan mempengaruhi perilaku pernikahan dini berdasarkan perspektif kesehatan reproduksi aman dan fiqih islam sebanyak 52 kali. Penting bagi bidan sebagai garda terdepan untuk memberikan KIE setiap melakukan pelayanan terkait kesehatan reproduksi remaja.

\section{REFERENSI}

Arikhman, N., Efendi, T. M. and Putri, G. E. (2019) 'Faktor yang Mempengaruhi Pernikahan Usia Dini di Desa Baru Kabupaten Kerinci', Kajian Ilmiah Problema Kesehatan, 4(3), pp. 470-480. Available at: http://ejournal.kopertis10.or.id/index.php/e ndurance/article/view/4614/1480.

Badan Pusat Statistik Jawa Timur (2017) Data Persentase Perempuan Jawa Timur Usia 10 Tahun Ke Atas yang Kawin di Bawah Umur (Kurang dari 17 Tahun) menurut Kabupaten/Kota, 2009-2016, Surabaya: BPS.

Bruno, L. (2019) Pernikahan Dini, Journal of Chemical Information and Modeling. doi: 10.1017/CBO9781107415324.004.

Ermawati, H. and Verawati, M. (2014) 'Kesehatan Ibu Dan Bayi Pada Pernikahan Dini', Media Ilmu Kesehatan, 3(3), pp. 132-139.

Glanz, K., Rimer, B.K., Viswanath, K. (2015). Health Behavior \& Health Education: Theory, Reseacrh and Practice 5th Edition, Jossey Bass, United States of Amerika, hal. 45-66; 211-236.

Ilmiah, W. S., Azizah, F. M. and Amelia, N. S. (2017) 'Pengetahuan tentang Alat Kontrasepsi dengan Inisiasi Berperilaku 
Pacaran Permisif pada Remaja di SMAN 1 Rambipuji - Jember', Sainmed, 9(1), pp. 62-68.

Indrawati, E. S. (2015) 'Status Sosial Ekonomi Dan Intensitas Komunikasi Keluarga Pada Ibu Rumah Tangga Di Panggung Kidul Semarang Utara', Jurnal Psikologi Undip, 14(1), pp. 52-57. doi: 10.14710/jpu.14.1.52-57.

Kartikawati, R. (2015) 'Dampak Perkawinan Anak di Indonesia', Jurnal Studi Pemuda, 3(1), pp. 1-16.

Miswanto (2014) 'Pentingnya Pendidikan Kesehatan Reproduksi dan Seksualitas Pada Remaja', Studi Pemuda, 3(2), pp. 111-121.

Muntamah, A. L., Latifiani, D. and Arifin, R. (2019) 'Pernikahan Dini Di Indonesia: Faktor Dan Peran Pemerintah (Perspektif Penegakan Dan Perlindungan Hukum Bagi Anak)', Widya Yuridika, 2(1), pp. 1-12. doi: $10.31328 /$ wy.v2i1.823.
Notoatmodjo, S. 2012. Promosi Kesehatan dan Perilaku Kesehatan, Jakarta: Rineka Cipta.

Pohan, N. H. (2017) ' Faktor yang Berhubungan dengan Pernikahan Usia Dini terhadap Remaja Putri.', Jurnal Endurance, 2(3), pp. 424-435. doi: 10.22216/jen.v2i3.2283.

Rifiani, D. (2011) 'Pernikahan Dini Dalam Perspektif Hukum Islam', Musãwa Jurnal Studi Gender dan Islam, 3(2), pp. 125134. doi: 10.14421/musawa.2009.82.201221.

Riskesdas (2013) Data Usia Pernikahan Perempuan, Jakarta: Kemenkes RI.

Rohan, hasdianah h. and Siyoto, S. (2013) 'Kesehatan Reproduksi', in Hand out Kesehatan Reproduksi, pp. 1-18.

UU Sisdiknas (2012). Tentang Sistem Pendidikan Tinggi, Jakarta: Kemendikbud.

Yasril. (2013). Teknik Sampling untuk Penelitian Kesehatan. Graha Ilmu: Yogyakarta. 